\section{ヒマラヤでの経験}

一医薬を中心にして一

\title{
小川鼎 三*
}

今から10年も前の見聞録で,ネパール国内の現状は これとだいぶ変っているはずである。「今日の医学」 Medizin von heute の第 5 巻第 3 号 (1960) 亿載せ たものを参考のためこの特集号に大体そのまま再録 する(小川)。

私ども雪男学術探検隊は1959年の11月10日に 羽田を発ってインドに向った。そしてカルカッ タでは荷物の通関などのことで数日をついや し，ネパールの首府カトマンズに着いてからは 探検の正式許可をとる手続きなどで更に10日ば かりかかった。目的地ソロクーンブ地区に向っ てのキャラバンはネパール東南部のダーラン バザールといら町からはじめる予定であった。

その町に私どもは11月26日に到着したが，荷 物がなかなか来ないので, また数日間ここで待 つより他なかった。テントや食糧がつくまで私 どもはやむなく污ない宿屋に泊ったが，吹ささ らしの露台に 1 枚の毛布をしいて葠るありさま で，食事は宿の主人や扔かみさんが親切に心使 いしてくれたにかかわらず，隊員の健康はその とき明らかに下り坂でめった。風邪をひいた り，腹をこわしたりするものが続出した。

往きのキャラバンが開始されたのは 12 月 2 日 の早朝で岁る。ポーター 100 人以上をやとい, 隊員は日本人 6 名とシェルパの親分ガルチェン ・ノルプ君を加えて 7 人, それにリエゾンオフ ィサー(ネパール政府が任命した連絡係り)のバ タライ君と道の案内やコックなどするシェルパ 数人がいるので, 全部で 110 人以上の相当な大 部隊である。道はさっそく険しい怔にかっった。

一同元気よく出発したと抏もっていたが，間 もなくポーターの一人が病気であることがわか

\footnotetext{
* 順天堂大学客員教授 (医史学)
}

った。初めは風邪であろらと考えたが, 熱も高 くて，それが何日もつづくので，肺炎でない か，またあるときは猩紅熱であるまいかなどと 心配した。この患者にはもちろん荷物をもたせ ず，彼を籠に大れて他のポーターに担がせて山 道をこえるのであった。担がれるものは後ろ向 きに椅子にのったかたちである。これがヒマラ ヤの山中で歩けなくなった病人をはこぶ唯一の 方法である。

この病気さわぎの最中に私どもの隊のシェル パの一人が打呪いの医術をする人間であること を耳にした。私どもが航生物質などを患者にめ たえている一方で，彼はその扮知いをやってい たらしい。そのやり方を見なかったのは残念で あるが，米粒などをまさながら病魔の退散を祈 るものらしかった。そのどちらが效いたのかわ からない㚙，幸いにして患者は命をとりとめた。

私どもの隊は日本人 6 名のうちで, 私と山崎 隊員が医事について責任をもっているわけであ る。土地の人々から診療の要求がしばしば括こ るのだが, 若先生の山崎君がそれに当り, 大先生 の私の活ら游なるべく医者としては正面にでな いで, 若先生の報告をらけてから,かげで虎の巻 を読んでいることが多かった。どちらも解剖学 の専攻なので, 二人足しても一人前の医者には 程と执い。若先生が出動して留守のばあいに患 者がくれば大先生がやむなく自らでて脈をとり 薬箱のなかをかきまおすといら有様であった。

往きのキャラバンは16日間めるきつづけて， 每日のよらに高い山をこ光, 深い谷をわたっ て, 北へ北へとヒマラヤの奥にすすむのであっ た。ポーターは初めは低い暖地の住人が多かっ たが，この人たちは寒い高い土地では充分に活 躍できなくなって，次第に寒地になれた人たち がそれに代るのであった。ある時は58人ものポ 
ーターをいらどに解雇しなければならなかっ た。そのときはポーターの補充がつかないで, 一部の荷物が本隊より光くれて運ばれることに なった。私どもは雪の降らないらちに目的地の ナムチェバザールに着こうとおもったので， 1 日も休まずに歩きつづけた。

12月17日ナムチェバザールに着いた。こ〉は 80 軒活どの民家がある村で，世界の最高峯エベ レストの西南に当って扎り，シェルパ族の故郷 として近年とみに登山界で有名になったところ である。チベットとの国境にも近いので，そこ との交易で最近チベットに動乱が扣こるまでは かなり賑わった所であるらしい。

私ど女はナムチェの西方約 $3 \mathrm{~km}$ 活どのプール テといら部落を基地にえらんで, こっに一切の 荷物を扣いて，付近の川すじに沿うて湖りなが ら雪男を探すことにした。それから50日にわた って西の方はラングモチェという溪谷やその両 岸の山々, 東の方はイムジャコーラといら川に そらてェベレストの麓めたりまで達した。基地 は海抜 3,500mの高さであり，捜索のあいだに 私自身は $4,800 \mathrm{~m}$ まて登ったが，隊員たちは時 として 5,500mまで登ったのでめる。高山病ら しいものに私自身が最初 4,500mに達したとき かかったが，間もなく回復して，それからは同 じ高さに登っても平気であった。

ヒマラヤの冬がどれくらい寒いのかは私ども 現地にゆくまで想像がつきかねたが，行ってみ ると思ったほど寒くなくて, 基地では最低気温 がー13度でめり，捜索の途中ではー20度といら のが一番低い気温であった。もっともこの冬は ヒマラヤも暖冬異変であったようである。

乾燥季であるとはい光, 私どもが目的地で行 動していたあいだ，雪が降らないことは全く意 外なことであり，そのため雪男の足あとを探す ことにはななはだ困難を感じた。ナムチェバザ ールで昨年の気像記録をみせてもらったが，そ の 1 月には 7 回も降雪があり, 多いときは 2.5 $\mathrm{m}$ も積ったと女るので今年雪が降らないのは異 常のことらしいのである。
その土地にすむ人は々チベット系のシェルパ 族であり，ラマ教のつよい支配下にある。そし てシェルパ族は高地の生活によく馴れていて, あきれる活ど高いところまで住んで扔り，ヤク やとッジを飼い，またジャガイモを植えてい る。もっとも彼らは夏の家と冬の家をもってい て，冬には家畜をつれて比較的低い土地で暮す のである。私どもは捜索にあたって空らになっ ている彼らの夏の家をしばしば利用させてもら った。森林限界はこの辺りでは $3,700 \mathrm{~m}$ ぐらい で，そこにはシャクナゲとダケカンバが多いよ らであった。

シェルパ族がどういら医術をやっているのか 遗憾ながらしらべる機会を逸したが，話による とラマ教の僧が主として医療をしているとのこ とであり，従ってチベット系の医術が行われて いることは確かで女ろう。ラサには古い医学校 が耊って僧医の養成が行われて扔り, 薬草 6,000 種が集められているといわれる。しかしラマ僧 たちも伝統のチベット医学だけでは病気がなか なか治らぬことを知り，新しい医学の効めを大 いにみとめていることはまちがいない。

その点で私自身の経験をいうと, 往さのキャ ラバンの終りに私どもはナムチェバザールで, チベットから避難してきたといら高僧にであっ た。高僧といっても, 年寄でなくて，13歳のか わいい少年であることに私どもは警いたが，そ の少年がこれから南の暑いところにゆくのだか らマラリアの薬をくれと云った。私どもは最新 の予防薬 (Resochin) をもっていたが，それは 余裕がないので, キニーネを差しあげた。

また雪男捜索の途中でたらよったチャンボチ ェのラマ寺ではそこの活仏が私どもに薬の余裕 がめったら欲しいとのことでめった。その活仏 は20数歳の青年である。使いの僧が私どもの基 地まで訪れてきて，いろいろな日本の薬を受け とっていった。るちろん私どもはその使用法を 英語で書いたものを付政てったのである。

坊さんのみでなく, 一般の住民も西洋医学の 有効を知っているので, プールテの基地をめが 
けて，あるいは私どもが通るのをまちらけて， しばしば病人がおとずれる。それは必ずしもお れわれが名医であるとの評判をさいたりして来 るのではなくて，探検隊にゆけば薬がある，岕 るいはそれをもらえると考えるのであるら。む かしオランダ商館長が江戸に東上するときも日 本人が同じようなぐあいで道にまちかまえたの であるまいか。

私どもの目的は雪男といわれるものが実在す るかについて証拠を求めることにあったので, 土地の人々が雪男の体の一部と称して保存して いるものを片っ端からしらべてみた。その保存 の目的が薬にするためといらのが時々あった。 その 1 例はナムチェに滞在中のラマ僧が薬用の 目的と称してもっていたく雪男の舌》で, これ は数年前チベットで殺されたものの舌であると のことであった。これは買いとることができた が，いかにも何かの哺乳類の舌らしい形をして いる。目下さらに研究中である。*1

他の例はガルチェン君がダージリンの漢方薬 の店でみつけてきたく雪男の骨》である。これ はブータンで捕えた雪男のものと云っていたの であった。私どもがしらべた結果, 偶蹄類の肢 の骨であり，イノシシかブタかその辺のもので あろらと思われた。《雪男》の体が薬とされる のはその魔力が人々に信ぜられているからであ ろら。

捜索の途上，パンボチェとクムジュンとナン チェバザール，つまり 3 カ所のラマ寺でく雪男 の頭皮》と称する宝物を見せてもらった。これ らについては後に詳報するが，《頭皮》はラマ 僧が扣祭りのとき頭にかぶるのであって, やは り悪魔を退けるという意味のものでめるらし い。それは薬用ではない。

私どもがヒマラヤで診た土地の人々の病気は 何が多かったかの問題は低い臨床的手腕のため に，確実な病名がさっぱりつけられなかったの であるが, 大ざっぱに云って, 皮膚病や結膜炎が

*1 (後に追加) これは舌ではなくチベット産アカ シカの尾であることが判明した。
かなり多く, 神経痛らしいものにもよく出会っ た。結核や性病も多いよらに聞いた。しかし民 家に往診して重い肺結核らしい患者が寝ている ことは経験しなかった。そらいうのは早く死ぬ のであろらか。特にめだつのは甲状腺腫すなわ

らStrumaが甚だ多いことで，ことに中年以上 の女性ののどに大きな塊りができている。それ でも山畸君の話ではマナスル地方では Struma はこ〉よりいっそら多いとのことであった。苦 痛はないらしく甲状腺腫を治してくれといら人 に私は一度出会っただけである。大きなのどを してみな平気で働いている。

平均寿命はどれくらいか分からないが，早 くから老けるのは確かである。中年の女性だと 思ったのに, 岁とで聞いて25歳ぐらいと知って 警いたことが嵓った。子供も年令のわりにませ ている。日本だったら小学校の 3 年生ぐらいか と思える子供が牛や羊をを追うて大人のように ふるまっている。その中にはクレチンも岕るら しい。

扣産や人が死んだときの処置については実際 にみる機会がなかった。それは私どもの基地プ 一ルテが戸数10ばかりの小村で岁って人口子少 ないことがその云いわけの一部にはなると扰も う。シェルパ族の扮産がごく軽くて, 赫ン坊を 生んだ翌日にはもら母親が逃げたニワトリを追 いまわしていたことを Bourdillon 夫人のくシ ェルパの村見聞記》(藤木九三氏訳) の中で読 んだ。

また人が死んだときの処置についてシェルパ にきくと, 焼いて川に流す, 子供は焼かないで 流すとのことであった。じっさい墓がヒマラヤ ではみられなかったので川に流すのは事実だろ らと考えた。チべットでは土葬を忌む風習があ ることは一般的に知られている。鳥葬*は私ど

* (編註) 鳥葬は一昨年春から秋にかけて西北ネパ ール地区探検の川喜田探検隊の大森カメラマンに よって世界ではじめて映画撮影に成功, 「秘境七 マラヤ」として本年 4 月から公開され, 好評を博 したことは周知であろう。なお，鳥葬見聞記も出 版されているので一読を括すすめしたい。(H.S) 
もの歩いた地方では行われている様子がなかっ た。

雪男の確証が光られないままに，私どもは 2 月 5 日に基地をたたんで，㷌途についた。こん どはポーターが 40 人ばかりで往きのキャラバン に較べると部隊がだいぶ小さいのであった。そ れは食糧が大部分なくなったからである。行軍 は14日間つづいて 2 月19日カトマンズにたど り着いた。往きとはちがった道をとおり, 西へ 西へと每日のように高い怔をこえたのである。

帰りのキャラバンが終りに近づいた或る朝の こと，私はりシンゴという村の近くで下りの山 道を独りで歩いていた。川向らから賑かな太鼓 の音がきこえてきた。眺めると向らがわの山の 尾根すじに何人かが集っていて，太鼓はそこか ら聞えてくるのでめった。半時間ばかりして私 はその一行と道の曲りかでで突然すれちがっ た。その人たちは太鼓をならすのを止めていた ので川を渡ってこちらにきたことを私は気づか ずにいたのである。みると，10名ばかりが一列 にならんで挄り，女が 3 名注どまじっていたの で, 私はとっさに結婚の行列だろらと考光て, すれがちいざまに写真をとった。

まもなく隊員のガルチェン君が追いついてき たので，あれは結婚かときいたら，いや医術を するもので，列の中匡どにいた鳥の羽を頭につ けていた男が神通力をもっており，祈㿧によっ て病人を治し，また死んだ人間の霊をよびもど すとのことであった。シャーマニズムだなと思 って，ふり返ってみたが，もら彼らは遠く離れ て姿がみえないのであった。この太鼓をたたく 行列が medicine man であることはとの日の 夕方，わが隊のリエゾンオフィサーであるバタ ライ君に尋㸚たとさも，すぐ彼がとれだと断言 したので，まず間違いないことと扰もら。

そのとき私は太鼓をたたいて広告しながら巡 業するのだなと考光たが，帰国後にMax Bartels の本 $<$ Medizin der Naturvölker, 1893》 を読んだでいて，原始医学では太鼓は音をだす 以外に重要な意味をもつことを知った。同じ調
子の太鼓の音をその後も時叔り山中で耳にした が，そらいら行列に実際でくわしたのはこの一 回だけであった。そして私は基地やその付近つ まりヒマラヤの奥深くでは同様な太鼓の音をき いたり，行列をみたりしなかったので，この風 習はシェルパ族の住む高い土地では行われてい ないと考えた。

帰りのキャラバンは 2 月 18 日の夕暮にバネパ という町に着いて解散した。こっからカトマン ズまでは短い距離だが自動車が使えるので, も ら歩く必要がないので女る。その夜私どもはバ ネパの町はずれで最後のテント生活をした。そ のキャンプ場の近くに米国のミッションが病院 をつくって，間もなく開業の運びになっている ようであった。病室の数は多くないが，きれい な建物であった。

私ども 3 ケ月にわたる山の中の旅で，病院あ るいは医院といえるものをみたのはこの時と， 往きのキャラバンの第 2 日ダンクータといら町 をと㧍った時だけでめった。ダンクータは地方 政庁の所在地であり，そこの病院は国立のもの らしかった。小さいが整った感じの建物であっ た。私は疲れていたのでその表てをと打りすぎ ただけで内部をみなかった。バネパもダンクー タもかなり大きい町でヒマラヤの山中とはい光 ない。

首府カトマンズにはいくつかの病院ないし医 院があり, 近年アメリカは 200 床の病院をこ〉 に設け、ソ連も300床の大きい病院をつくる計 画があるときいた。ソ連は現在すでに50床のも のをもっている由である(バタライ君の話)。 またこの国には医学校の設けがなくて医学の修 業は他国（主としてインド）の大学で受けるこ とになっている。

ネパール国の都会地では医療の備えが或る程 度できている。しかし一歩山の中に大るとヒマ ラヤの広い地域が無医村といらに等しい状態で める。扮呪いの医術が扰こなわれ，病人はラマ 僧のもっている草根木皮に頼る他はないのであ る。雪男と称せられるものまで薬にされてい 
る。しかもこの広、無医村の人口が決して少 なくないのであって，ネパールの総人口 800 万 として，そのうち医療設備の安る都会地にすむ ものは 100万に達しないであろら。

私どもの隊をめがけてずいぶん数多くの人々 が治療を求めてきた。帰りのキャラバンの途中 で，腕に大やけどした女の子を抱いて道ばたに
立って，われらのと扔るのを待っていた父親の 憂いにみちた顔がいま子私の眼底にのこるので める。

（付記）この旅行の正式な結果報告は日本人類学会 日本民族学協会連合大会第15回紀事 (昭和 36 年 10 月発行) に載っている。

若年性リウマトイド関節炎における虹彩毛様体炎

Iridocyclitis in Juvenile Rheumatoid Arthritis

Jane Schaller et al; Pediat, 44 (1): 92, 1969

若年性リウマトイド関節炎の患児70例中 8 例が虹 彩毛㥞体炎をおこした。この合併症は多発性関節炎 のあるものよりも関節炎の個所が少ないものに多か った。 8 例中 7 例がそうで, 硬直性の全椎炎などは おこさなかった。8例中の 2 例では虹彩毛様体炎が 関節炎に先立ったが，6例では関節炎のあとでおこ った。

虹彩毛様体炎は関節炎とは関係なくおこり，多く は片側におこり，視力を障害し，治療に抵抗した。
虹彩毛様体炎は若年性リウマトイド関節炎の患児 を無能にする大きな原因である。この初期症状は僅 かなもの,で関節症状も少ないものがかかりやすい。 眼の永久的な傷害を予防するために早期発見と早期 治療が必要である。リウマトイド関節炎の患児はル チーンに注意深く眼の検查をうけるべきであり，関 節炎が寛解した後も定期的にスリットランプ検查を らけるべきである。

（小児科 加藤） 